\title{
Matéria
}

ISSN 1517-7076

Revista Matéria, v. 14, n. 3, pp. 993 - 999, 2009

http://www.materia.coppe.ufrj.br/sarra/artigos/artigo11069

\section{Magnetic properties and retained austenite quantification in SAE 4340 steel}

\author{
AJUS $^{\text {I }}$, C.; TAVARES ${ }^{\text {I }}$, S.S.M.; SILVA ${ }^{\mathrm{II}}$, M.R.; CORTE ${ }^{\mathrm{I}}$, R.R.A. \\ IUniversidade Federal Fluminense - Departamento de Engenharia Mecânica, Rua Passo da Pátria, 156 - CEP \\ 24210-240, Niterói, RJ, Brazil \\ e-mail: ajus@unisys.com.br, ssmtavares@terra.com.br, raissacorte@hotmail.com
}

IIUniversidade Federal de Itajubá - Instituto de Ciências, Departamento de Física e Química - Avenida B. P. S., 1303 Pinheirinho 37500-903 - Itajubá, MG, Brasil - Caixa-Postal: 50

e-mail: mrsilva@unifei.edu.br

\begin{abstract}
Magnetic properties (coercive force and saturation magnetization) of SAE 4340 steel, heat treated in different ways, were measured in a Vibrating Sample Magnetometer. Four soaking temperatures were investigated: $860^{\circ} \mathrm{C}, 960^{\circ} \mathrm{C}, 1060^{\circ} \mathrm{C}$ and $1160^{\circ} \mathrm{C}$. The oil-quenched samples were tempered at different temperatures between the range of $200^{\circ} \mathrm{C}$ and $650^{\circ} \mathrm{C}$. The increase of the soaking temperature promotes the decrease of the saturation magnetization, which is mainly due to the retained austenite in the steel. This austenite transforms into bainite during tempering between $200^{\circ} \mathrm{C}$ and $300^{\circ} \mathrm{C}$. The saturation magnetization measurements were used to quantify the amount of retained austenite in the different samples. The coercive force of the steel varied from 115.0 Oe $(9151.7 \mathrm{~A} / \mathrm{m})$ to 133.0 Oe $(10584.1 \mathrm{~A} / \mathrm{m})$, depending on the heat treatment condition.
\end{abstract}

Keywords: Magnetic properties, retained austenite, SAE 4340 steel.

\section{INTRODUCTION}

Magnetic materials are divided into two groups: soft and hard magnets. The latter must present high coercive field $\left(\mathrm{H}_{\mathrm{c}}\right)$ and saturation magnetization $\left(\mathrm{m}_{\mathrm{s}}\right)$ or induction $\left(\mathrm{B}_{\mathrm{s}}\right)$. Soft magnetic materials must show high magnetic permeability and low $\mathrm{H}_{\mathrm{c}}, \mathrm{m}_{\mathrm{s}}, \mathrm{B}_{\mathrm{s}}$. The hysteresis loop must be high and thin.

For some specific uses, there is a demand for high strength materials, with soft magnetic properties. This is a problem because, in general, materials that present high mechanical strength also present a greater magnetic hardness.

One of the applications for materials with soft magnetic properties and high strength is in the rotors of ultra-high speed engines used in the nuclear industry. For this application maraging steels have been used in the aged condition [1-2]. However, maraging steels are high cost materials and, frequently, not available for nuclear power generation in developing countries.

SAE 4340 steel has demonstrated interesting applications where good mechanical and magnetic properties are necessary, at a low cost. This steel presents a good hardening ability that promotes the improving of its mechanical properties when submitted to quenching and tempering.

The behaviour of coercive force and saturation magnetization as a function of soaking and tempering temperatures were investigated in this paper. An equation to measure the amount of retained austenite as a function of $\mathrm{M}_{\mathrm{s}}$ was suggested.

\section{MATERIALS AND METHODS}

Cylindrical samples, with a diameter of 3.5mm, of SAE 4340 steel (chemical composition shown in table 1) were machined and oil quenched. Four soaking temperatures were investigated: $860^{\circ} \mathrm{C}, 960^{\circ} \mathrm{C}$, $1060^{\circ} \mathrm{C}$ and $1160^{\circ} \mathrm{C}$. After that, the cylindrical samples were cut into slices with a thickness of $0.3 \mathrm{~mm}$ by wire electro-erosion. These samples were tempered for 1 hour at different temperatures from $200^{\circ} \mathrm{C}$ to 
$650^{\circ} \mathrm{C}$, at intervals of $50^{\circ} \mathrm{C}$. Magnetic measurements were carried out in a Vibrating Sample Magnetometer (VSM) with a maximum applied field of $0.5 \mathrm{~T}$, at a time constant of $10 \mathrm{~ms}$ and a total measuring time of 20 minutes.

The samples were etched, for microstructure analysis, with nital $2 \%$ (solution 1 ) or with a solution of picric acid and ferric chloride (solution 2) which reveals prior austenite grain boundaries. Microstructures were analyzed by optical microscopy and X-ray diffraction techniques. Vickers hardness measurements were also carried out for all the heat treatment conditions, with a load of 30kgf.

Table 1: Chemical Composition of SAE 4340 steel

\begin{tabular}{|c|c|c|c|c|c|c|c|}
\hline \%C & \%Si & \%Mn & \% S & \%P & \%Cr & \%Ni & \%Mo \\
\hline 0.410 & 0.240 & 0.620 & 0.016 & 0.019 & 0.740 & 1.670 & 0.270 \\
\hline
\end{tabular}

Iron: remaining

\section{RESULTS}

Figure 1 shows the behaviour of coercive force $\left(\mathrm{H}_{\mathrm{c}}\right)$ versus tempering temperature as a function of the soaking temperature. It is observed in this figure that $\mathrm{H}_{\mathrm{c}}$ increases slightly with the soaking temperature for the untempered samples. Figures 2(a) and 2(b) show the microstructures of quenched samples at $860^{\circ} \mathrm{C}$ and $1060^{\circ} \mathrm{C}$. In these micrographs the prior austenite grain boundaries were revealed by solution 2 . The average austenite grain sizes in the quenched samples were determined by quantitative metallography and listed in Table 2.

Slightly higher values of coercive force were obtained in samples quenched from higher temperatures $\left(1060^{\circ} \mathrm{C}\right.$ and $\left.1160^{\circ} \mathrm{C}\right)$. However, the influence of the soaking temperature on the $\mathrm{H}_{\mathrm{C}}$ is a lot less important than expected when considering the differences of prior austenite grain sizes and retained austenite volume fractions. As observed by Battistini, and Benasciutti [5] in ferritic stainless steel, the coercive force, generally, tends to decrease with an increase of the grain size. This effect was not observed in the SAE 4340 steel.

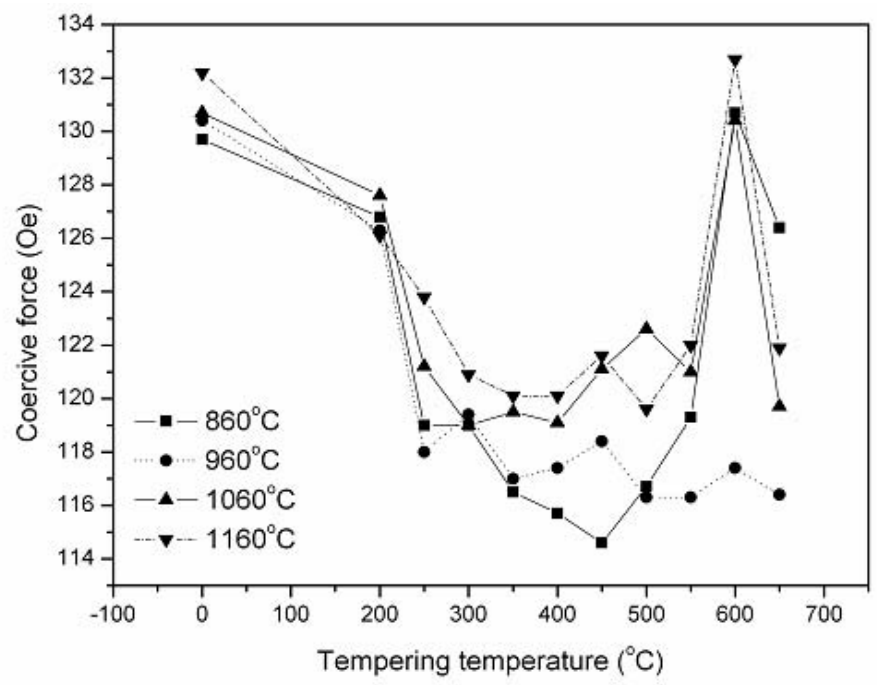

Figure 1: Coercive force behaviour as a function of tempering temperature

The coercive force decreases as a function of tempering temperature and presents the lowest values between $300^{\circ} \mathrm{C}$ and $500^{\circ} \mathrm{C}$. The smallest $\mathrm{H}_{\mathrm{c}}$ value $(115.0$ Oe or $9151.7 \mathrm{~A} / \mathrm{m})$ was found in the sample quenched at $860^{\circ} \mathrm{C}$ and tempered at $450^{\circ} \mathrm{C}$. A significant increase of $\mathrm{H}_{\mathrm{c}}$ was observed in the sample quenched at $860^{\circ} \mathrm{C}, 1060^{\circ} \mathrm{C}$ and $1160^{\circ} \mathrm{C}$, and tempered at $600^{\circ} \mathrm{C}$. Similar results were also presented by Berti Neto et al. [3], who observed a significant decrease of $\mathrm{H}_{\mathrm{c}}$ between $200^{\circ} \mathrm{C}$ and $300^{\circ} \mathrm{C}$ and a small increase at $600^{\circ} \mathrm{C}$ in samples quenched with a soaking temperature of $870^{\circ} \mathrm{C}$. 

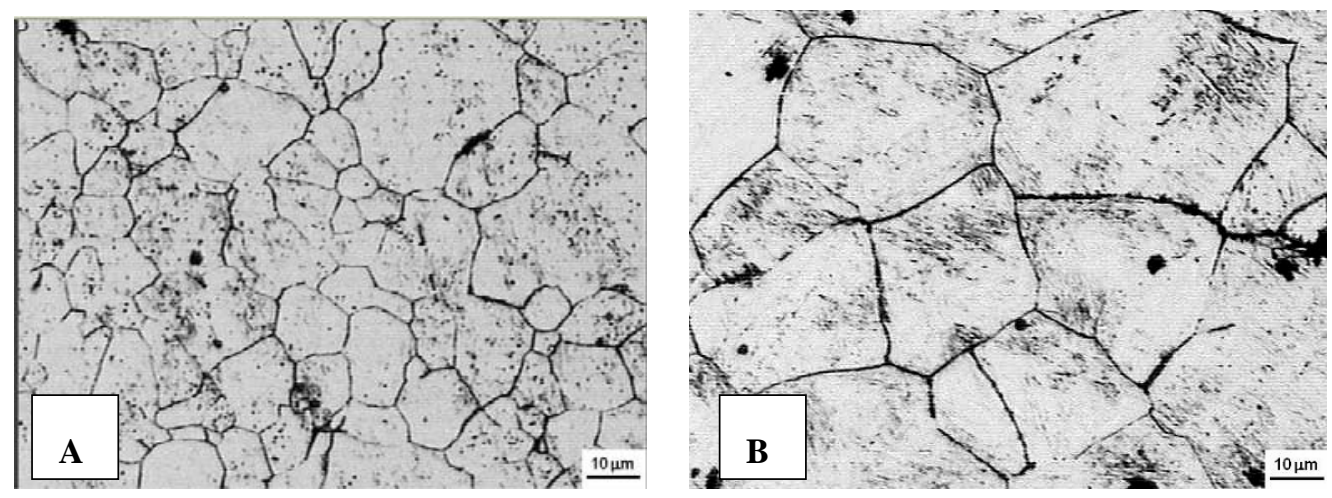

Figure 2: (a) Austenite grain boundaries of quenched steel at $860^{\circ} \mathrm{C} .800 \mathrm{X}$; (b): Austenite grain boundaries of quenched steel at $1060^{\circ} \mathrm{C} .800 \mathrm{X}$.

Table 2: Average grain size at different soaking temperatures

\begin{tabular}{|c|c|c|}
\hline Soaking Temperature $\left({ }^{\circ} \mathrm{C}\right)$ & Average Grain Size $(\mu \mathrm{m})$ & Standard Deviation $((\mu \mathrm{m})$ \\
\hline 860 & 19 & 2 \\
\hline 960 & 22 & 3 \\
\hline 1060 & 36 & 14 \\
\hline 1160 & 61 & 6 \\
\hline
\end{tabular}

It is interesting to show the variation curves of mechanical hardness against tempering temperature and observe how the increase of soaking temperature above $860^{\circ} \mathrm{C}$ decreases the hardness, not only in the quenched samples but also in all the tempered conditions (Figure 3). A correlation between mechanical and magnetic hardness is always searched for in metallic materials because the hardening mechanism tends to impede the magnetic domains wall motion. Indeed, in the case of quenched and tempered SAE 4340 steel the increase of tempering temperature decreases both the $\mathrm{H}_{\mathrm{c}}$ value and hardness, except for the increase of $\mathrm{H}_{\mathrm{c}}$ in the tempering at $600^{\circ} \mathrm{C}$.

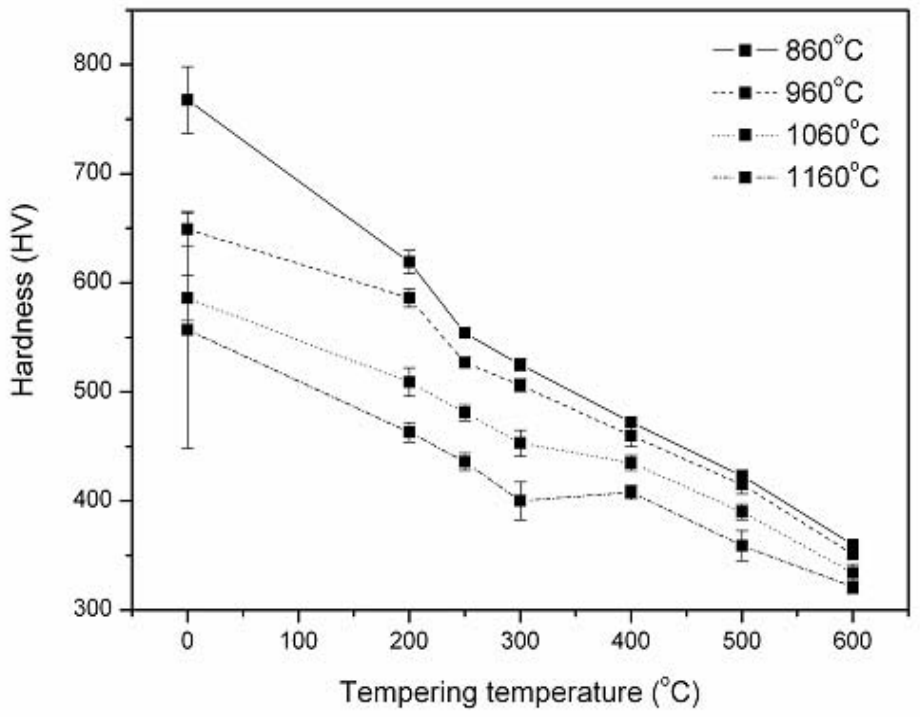

Figure 3: Hardness as a function of tempering temperature. 
In Figure 4(b), for the sample quenched from $1060^{\circ} \mathrm{C}$, light regions of retained austenite between coarse martensite laths can be observed. The sample quenched from $860^{\circ} \mathrm{C}$ (Fig. 4(a)) presents a finer martensite structure, where it is not possible to distinguish nor quantify the retained austenite. In agreement, Figs. 5 and 6 show the X-rays diffractograms of samples quenched from $860^{\circ} \mathrm{C}$ and $1060^{\circ} \mathrm{C}$, respectively. Austenite reflections are observed in the sample quenched from $1060^{\circ} \mathrm{C}$ but not in the one quenched from $860^{\circ} \mathrm{C}$.
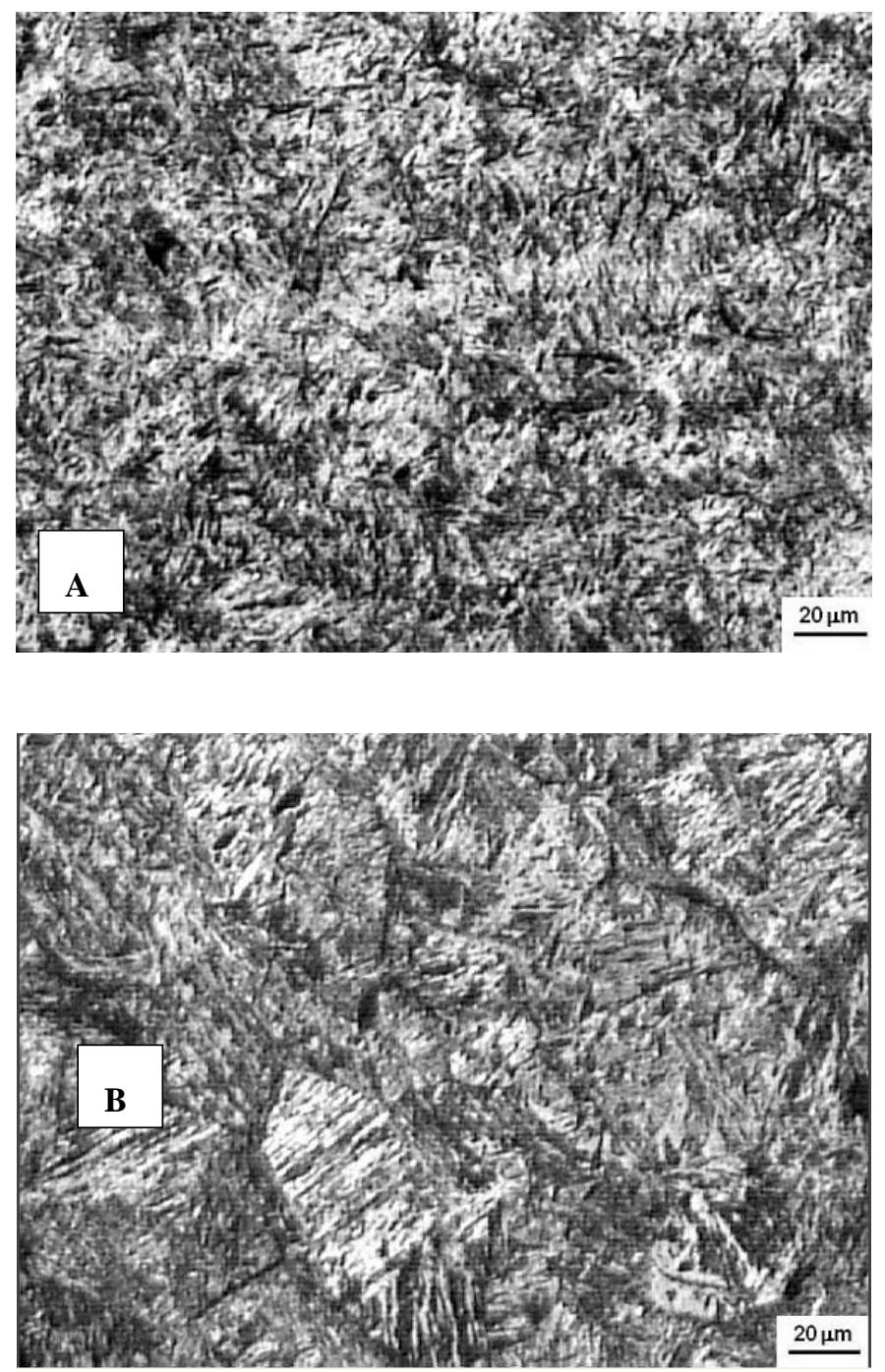

Figure 4: (a) microstructure of sample quenched at $860^{\circ} \mathrm{C}$; (b) microstructure of sample quenched at $1060^{\circ} \mathrm{C}$. 


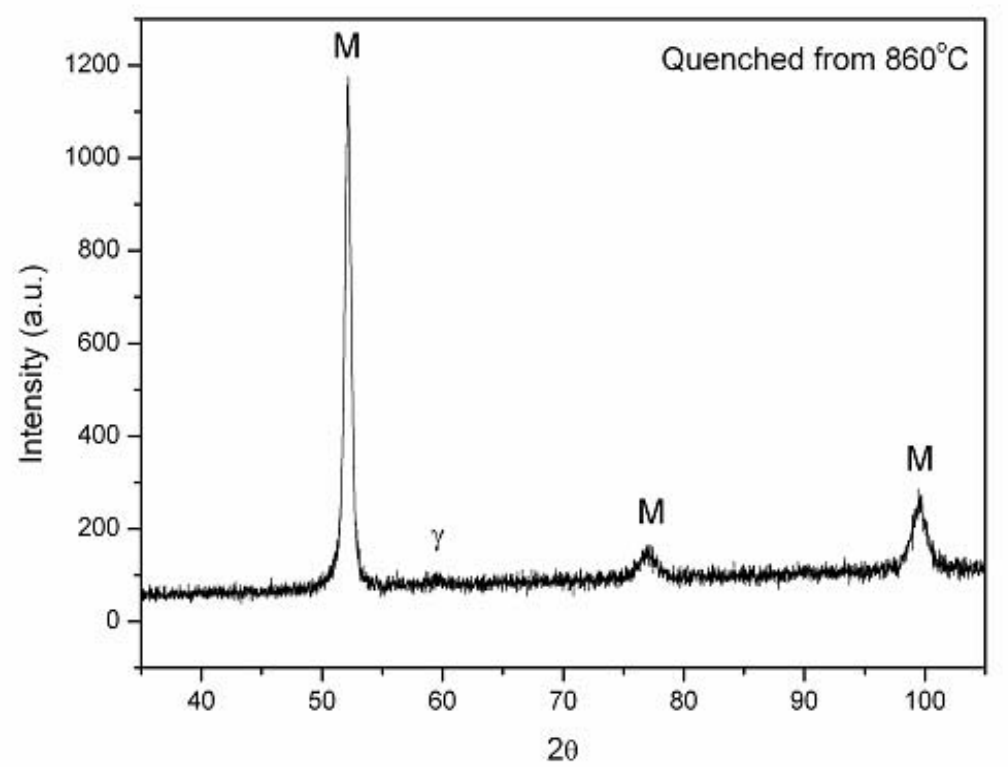

Figure 5: Diffractogram of sample quenched at $860^{\circ} \mathrm{C}$. Radiation $\mathrm{CuK} \alpha$

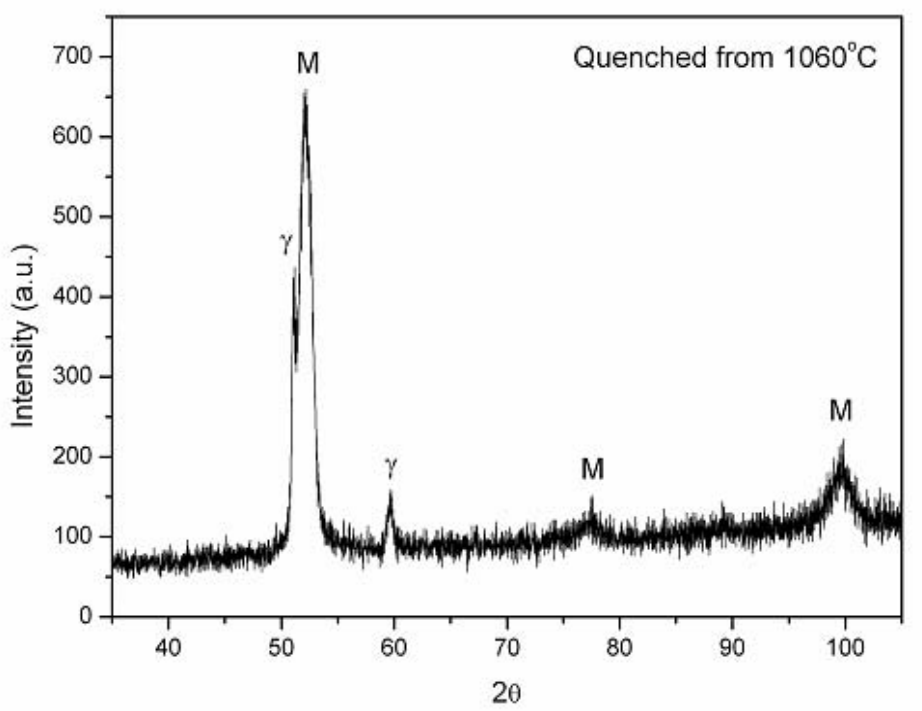

Figure 6: Diffractogram of sample quenched at $1060^{\circ} \mathrm{C}$. Radiation $\mathrm{CuK} \alpha$.

Figure 7 shows the saturation magnetization behaviour versus tempering temperature as a function of soaking temperature. It can be observed from this figure, that, the increase of soaking temperature promotes a decrease in saturation magnetization due to the increasing amount of retained austenite in the untempered samples.

Retained austenite transforms into lower bainite between $200^{\circ} \mathrm{C}$ and $300^{\circ} \mathrm{C}$, promoting maximum values of saturation magnetization. After this point, there is a gentle decrease in the samples quenched at $860^{\circ} \mathrm{C}, 1060^{\circ} \mathrm{C}, 1160^{\circ} \mathrm{C}$ and tempered at $600^{\circ} \mathrm{C}$. 


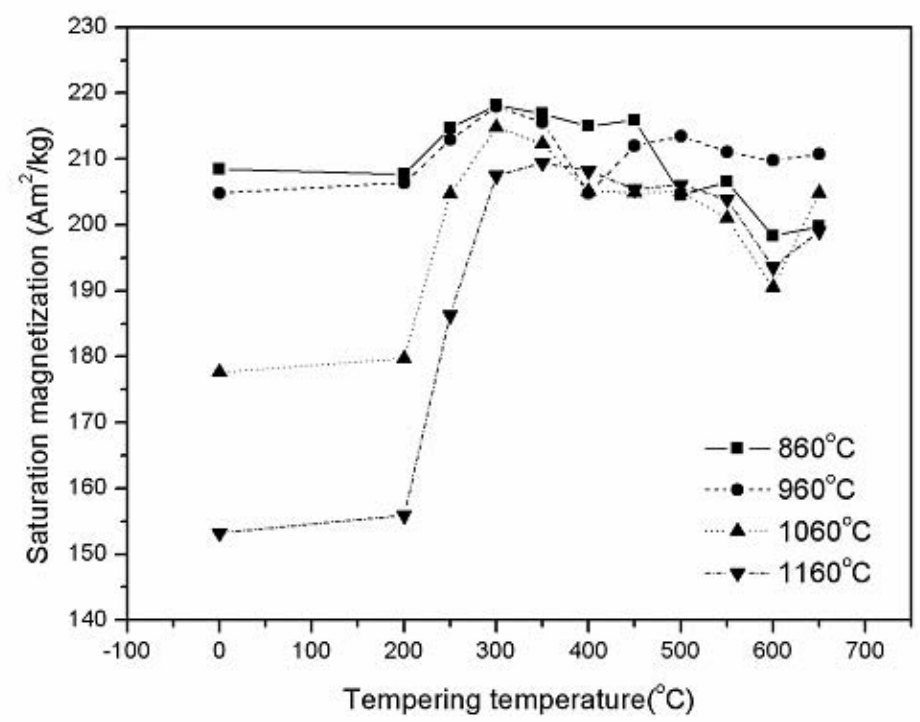

Figure 7: Saturation magnetization $\left(\mathrm{m}_{\mathrm{s}}\right)$ behaviour as a function of tempering temperature

The maximum value of saturation magnetization was $218.0 \mathrm{~A} \cdot \mathrm{m}^{2} / \mathrm{kg}$, obtained in samples quenched at $860^{\circ} \mathrm{C}$ and $960^{\circ} \mathrm{C}$ and then tempered at $300^{\circ} \mathrm{C}$. In such conditions, all the austenite paramagnetic was transformed and the carbide precipitation was negligible. Considering, the value of saturation magnetization at this condition as the intrinsic $\mathrm{m}_{\mathrm{s}}$ of martensite, it is possible to calculate the austenite volume fraction $\left(\mathrm{C}_{\gamma}\right)$ as a function of saturation magnetization $\left(\mathrm{m}_{\mathrm{s}}\right)$ of the sample by the following expression:

$$
C_{\gamma}=1-\frac{m_{s}}{218}
$$

Expressions like this were also developed for other types of material and, despite their simplicity, they can be used to measure the phase amounts when the microstructure contains a ferromagnetic phase and a paramagnetic one [5]. This is particularly useful when other quantification methods like metalography and Xray diffraction gives an un-precise result. The experimental difficulty is to determine the intrinsic magnetic saturation of the ferromagnetic phase, which, for the case sited is $218 \mathrm{~A} \cdot \mathrm{m}^{2} / \mathrm{kg}$.

Equation (1) can be used to quantify the austenite volumetric fraction of SAE 4340 steel. The value of saturation magnetization of martensite is very sensitive to the chemical composition of the steel. In a previous work [6] the intrinsic saturation magnetization of martensite of a high carbon steel containing $0.95 \% \mathrm{Cr}$ and $0.20 \%$ Mo was measured as $206.4 \mathrm{Am}^{2} / \mathrm{kg}$.

In another research paper, Mangonon and Thomas [7] reported the intrinsic saturation magnetization of martensite as $164 \mathrm{~A} . \mathrm{m}^{2} / \mathrm{kg}$ in AISI 304 steels.

\section{CONCLUSIONS}

Quenched SAE 4340 steel presents a coercive force of 130.0 Oe (10345.4 A/m). After tempering that value decreases, reaching the smallest values after tempering between $300^{\circ} \mathrm{C}$ and $500^{\circ} \mathrm{C}$. The increasing of soaking temperature for quench temperature tends to slightly raise the coercive force.

The minimum value encountered for coercive force was 115.0 Oe $(9151.7 \mathrm{~A} / \mathrm{m})$, which was obtained in the sample treated at $860^{\circ} \mathrm{C}$ and tempered at $450^{\circ} \mathrm{C}$. At this condition the saturation magnetization was $216 \mathrm{Am}^{2} / \mathrm{kg}$ and the hardness was near to 400HV. This combination of mechanical and magnetic properties may be interesting as an application to soft magnetic and high strength materials used in the rotors of ultra-high speed engines used in the nuclear industry. Similar properties are obtained by maraging steels but at a much higher cost.

The increase of the soaking temperature promotes the increase of the retained austenite after quenching, and consequently the decrease of the saturation magnetization.

This austenite transforms into bainite during tempering between $200^{\circ} \mathrm{C}$ and $300^{\circ} \mathrm{C}$ and promotes the increase of saturation magnetization. 
The retained austenite volumetric fraction of SAE 4340 steel quenched and tempered until $300^{\circ} \mathrm{C}$ can be calculated using the simple expression:

$$
C_{\gamma}=1-\frac{m_{s}}{218}
$$

\section{ACKNOWLEDGEMENTS}

The authors acknowledge the financial support from FAPERJ and CNPq.

\section{REFERENCES}

[1] TAVARES, S.S.M., DA SILVA, M.R., NETO, J.M., PARDAL, J.M. CINDRA FONSECA, M.P. and ABREU, H.F.G, “Magnetic properties of a Ni-Co-Mo-Ti maraging 350 steel”, Journal of Alloys and Compounds, v. 373, p. 304-311, 2004.

[2] TAVARES, S.S.M., DA SILVA, M.R., NETO, J.M., ABREU, H.F.G. and POPA, I. “A magnetic study of the maraging 350 Steel”, Journal of Magnetism and Magnetic Materials, v. 272-76, n. P2, p. 785787, 2004.

[3] BERTI NETO, H., LANDGRAF, F.J.G., FUKUHARA, M., TSCHIPTSCHIN, A.P., GOLDENSTEIN, H., "Comportamento magnético do aço ABNT 4340 temperado e revenido." In: $60^{\circ}$ Congresso Anual da ABM, Belo Horizonte, Anais do 60. Congresso Anual da ABM, São Paulo, 005, pp. 16961706, 2005.

[4] BATTISTINI, L. BENASCIUTTI, R., TASSI, A, "Effects of heat treatment on crystallographic and magnectic properties of magnetic steels”, Journal of Magnetism and Magnetic Materials, v.133, pp.603-606, 1994.

[5] CULLITY, B.D., GAHAN, C.D., “Introduction to Magnetic Materials”, $2^{\text {nd }}$ Edition, Wiley, 2009, Hoboken, USA.

[6] TAVARES, S.S.M., DA SILVA, M.R., MARIA NETO, J., MELLO, S.R., GOMES, A.M., PARDAL, J.M, "X-ray Diffraction and Magnectic Characterization of the Retained Austenite in a Chromium Alloyed High Carbon Steel”, Journal of Materials Science, v.41, pp.4732-4736, 2006.

[7] MANGONON, P.L., THOMAS, G., "The martensite phases in 304 stainless steel, Metal.l Trans 1, v.1, pp.1577-1586, 1970. 